\title{
PENGARUH CITRA MERK, HARGA DAN KUALITAS PELAYANAN TERHADAP KEPUASAN PELANGGAN
}

\author{
Masitha Kurnia Sari Siregar \\ Fakultas Ekonomi, STIE Akuntansi dan Bisnis Internasional \\ siregar.sitha@yahoo.com
}

\begin{abstract}
This study will examine the presence or absence of the Effect of Brand Image, Price and Service Quality on Customer Satisfaction. The first test is to test the validity and reliability so that the questionnaire to be distributed to respondents is valid and reliable. After that, an assessment of the magnitude of influence will be carried out using the correlation, regression, $t$-test and f-test methods assisted by the SPSS version 18.00 application. Thus the magnitude of the influence of each variable is identified (Brand Image, Price and Service Quality) on Customer Satisfaction. The calculation results of the SPSS version 18.00 application indicate that each variable has an influence on Customer Satisfaction with the Price level being strong, Brand Image strong and Service Quality weak.
\end{abstract}

Kata Kunci : Citra Merek, Harga, Kualitas Pelayanan, Kepuasan Pelanggan

\section{PENDAHULUAN}

Citra merek (Brand Image) memegang peranan penting dalam pengembangan sebuah perusahaan karena citra merek menyangkut nama baik dari produk atau jasa suatu perusaaan tersebut. Citra merek dapat sebagai "pedoman" bagi konsumen untuk mencoba atau menggunakan suatu produk atau jasa sehingga menimbulkan pengalaman tertentu (brand experience). Selain itu citra merek dapat mencerminkan pencitraan suatu perusahaan. Citra merek yang baik akan berdampak positif bagi perusahaan karena mampu memberikan kepuasan kepada konsumennya, sehingga dapat meningkatkan daya tarik konsumen untuk menggunakan produk atau jasa perusahaan tersebut. Konsumen yang memiliki citra yang positif terhadap suatu merek akan lebih memungkinkan untuk melakukan pembelian ulang (Setiadi, 2003: 180). Harga adalah satu-satunya unsur yang akan mendatangkan laba bagi perusahaan. Dalam pengertian strategi harga, harga merupakan salah satu unsur yang mempengaruhi kegiatan-kegiatan dalam perusahaan yang berfungsi menciptakan keunggulan kompetitif bagi perusahaan. Namun, hal itu seringkali terbentur pada kebijakan penetapan harga.Penetapan harga oleh perusahaan harus disesuaikan dengan situasi lingkungan dan perubahan yang terjadi terutama pada saat persaingan yang semakin ketat dan perkembangan permintaan yang terbatas. Dalam iklim persaingan yang ketat seperti sekarang ini, perusahaan harus memperhatikan faktor harga, karena besar kecilnya harga yang ditetapkan akan sangat mempengaruhi kemampuan perusahaan dalam bersaing dan juga mampu 
mempengaruhi konsumen untuk mengunakan jasa perusahaan. Agar lebih kompetitif di pasar, perusahaan dapat mempertimbangkan harga pesaing sebagai pedoman dalam menentukan harga jual jasanya.

Kualitas pelayanan menjadi kunci dalam upaya organisasi untuk mencapai kepuasan dan hubungan jangka panjang dengan pelanggan dan juga menarik pelanggan baru. Untuk mencapai tujuan tersebut perusahaan seharusnya memperhatikan tindakan pekerja dan membekali pekerjaannya dengan pengetahuan yang cukup tentang strategi pelayanan yang baik, apabila hal ini diabaikan maka pelanggan akan mengalami kekecewaan karena komunikasi yang buruk. Kesuksesan suatu perusahaan sangatlah ditentukan oleh pelanggan (Jugdip\&Lele, 2000). Oleh karena itu, setiap perusahaan berusaha untuk memberikan kualitas pelayanan yang baik dan berusaha untuk menyesuaikan kebutuhan dan keinginan pelanggan. Kepuasan para pelanggan merupakan salah satu faktor yang menentukan daya saing untuk memenangkan persaingan. Sebab apabila pelanggan tidak puas mereka akan menyikapi dengan meninggalkan perusahaan dan beralih menjadi pelanggan pihak pesaing, hal ini akan menyebabkan penurunan laba dan pada akhirnya akan menyebabkan kerugian bagi perusahaan. Hal ini didukung dengan tingkat kecepatan dari fasilitas yang diberikan menjadi tujuan utama, sehingga pengiriman menjadi lebih cepat dan terjamin. Dalam hal pengiriman paket dituntut untuk selalu meningkatkan kualitas layanan melalui perluasan jangkauan, peningkatan kecepatan waktu tempuh yang cepat dan terjamin serta ketanggapan dalam pelayanan akan mempengaruhi konsumen memutuskan jasa pengiriman paket yang akan dipilihnya berdasarkan pengalaman konsumen sehingga mengambil sikap menentukan keputusan pemilihan.

PT. Pos Indonesia (Persero) merupakan perusahaan negara yang memberikan pelayanan, namun dalam kenyataan yang terjadi pada pelayanan PT Pos Indonesia (Persero) inilah yang tetap dikeluhkan masyarakat pengguna jasa. Hal ini terjadi karena banyak industri jasa pengiriman yang menawarkan nilainilai yang lebih seperti kecepatan, ketepatan sampai di tujuan, jangkauan yang lebih luas, jaminan saat pengiriman paket, harga yang diberikan dan lain sebagainya. Jika hal ini dibiarkan, PT. Pos Indonesia (Persero) dalam jangka panjang dapat kehilangan pelanggannya.

\section{KAJIAN TEOROTIS}

Citra merek meliputi pengetahuan dan kepercayaan akan atribut merek, konsekuensi dari penggunaan merek tersebut, dan situasi penggunaan yang sesuai, begitu juga dengan evaluasi, perasaan dan emosi yang diasosiasikan dengan merek tersebut. Citra merek didefinisikan sebagai persepsi konsumen dan preferensi terhadap merek, sebagaimana yang direfleksikan oleh berbagai macam asosiasi merek yang ada dalam ingatan konsumen. Menurut Aaker dalam Rangkuti (2008:43) "menyatakan bahwa asosiasi merek adalah segala hal berkaitan dengan ingatan mengenai sebuah merek". Asosiasi tidak hanya eksis namun juga memiliki suatu tingkatan kekuatan keterkaitan pada suatu merek akan lebih kuat apabila dilandasi pada banyak pengalaman atau penampakan untuk mengomunikasikannya, ditambah lagi jika kaitan tersebut didorong oleh suatu jaringan dari kaitan-kaitan lain.

Menurut Kotler dan Armstrong (2008) yang diterjemahkan oleh Sabran, harga merupakan sejumlah uang yang ditagihkan atas suatu produk atau jasa, atau jumlah dari nilai yang ditukarkan para pelanggan untuk memperoleh manfaat dari memiliki atau menggunakan suatu produk atau jasa. Menurut Kotler dan Keller (2009) menyatakan bahwa harga adalah elemen dalam bauran pemasaran yang tidak saja menentukan profitabilitas tetapi juga sebagai sinyal untuk mengkomunikasikan proporsi nilai suatu produk. Pemasaran 
produk perlu memahami aspek psikologis dari informasi harga yang meliputi harga referensi (reference price), inferensi kualitas berdasarkan harga (prce-quality inferences) dan petunjuk harga (price clues).

Pengertian kualitas pelayanan menurut J.Supranto (2006:226) adalah sebuah kata yang bagi penyedia jasa merupakan sesuatu yang harus dikerjakan dengan baik. Sedangkan definisi pelayanan menurut Gronroos adalah suatu aktivitas atau serangkaian aktivitas yang bersifat tidak kasat mata yang terjadi sebagai akibat adanya interaksi antara konsumen dengan karyawan atau hal-hal lain yang disediakan oleh perusahaan pemberi pelayanan yang dimaksud untuk memecahkan permasalahan konsumen / pelanggan (Ratminto, 2005:2).

Menurut Kotler yang dikutip kembali oleh Fandy Tjiptono (2012:312) kepuasan konsumen adalah tingkat perasaan seseorang setelah membandingkan kinerja (atau hasil) yang ia persepsikan dibandingkan dengan harapannya. Menurut Kotler dan Keller (2009:138) kepuasan (satisfaction) adalah perasaan senang atau kecewa seseorang yang timbul karena membandingkan kinerja yang telah dipersepsikan produk (atau hasil) terhadap ekspektasi mereka. Jika kinerja gagal memenuhi ekspektasi , pelanggan akan tidak puas. Jika kinerja sesuai dengan ekspektasi, pelanggan akan puas. Jika kinerja melebihi ekspektasi, pelanggan akan sangat puas atau senang.

Dalam mencapai tujuan yang di harapkan, maka suatu insitusi harus dapat meningkatkan kepuasan pelanggan. Begitu pula instansi pemerintah harus mempunyai kemampuan dalam melayani masyarakat dalam hal jasa pengiriman. Dimana pada masa sekarang jasa pengiriman sangat di harapkan oleh masyarakat luas, jadi dalam penelitian ini dapat di kemukakan kerangka berpikir terhadap :

\section{a. Pengaruh Citra Merek terhadap Kepuasan Pelanggan}

Citra Merek akan berhasil dan berjalan dengan lancar dan berkualitas apabila setiap pihak yang berkepentingan akan memberikan informasi kepada setiap pelanggan yang akan datang untuk mendapatkan semua jasa pengiriman. Dimana semakin banyaknya jasa pengiriman yang di indonesia sehingga semakin banyak daya saing jasa pengiriman. Wicaksono (2007) mengemukakan pentingnya pengembangan citra merek dalam keputusan penggunaan jasa. Brand image yang dikelola dengan baik akan menghasilkan konsekuensi yang positif, meliputi:

1) Meningkatkan pemahaman terhadap aspek-aspek perilaku konsumen dalam mengambil keputusan pembelian.

2) Memperkaya orientasi konsumsi tehadap hal-hal yang bersifat simbolis lebih dari fungsi-fungsi produk.

3) Meningkatkan kepercayaan konsumen terhadap produk.

4) Meningkatkan keunggulan bersaing berkelanjutan, mengingat inovasi teknologi sangat mudah untuk ditiru oleh pesaing.

Penciptaaan kesan kepada pelanggan menjadi salah satu karateristik dasar dalam orientasi pemasaran modern yaitu lewat pemberian perhatian lebih serta penciptaan merek yang baik dan kuat. Implikasi dari hal tersebut menjadikan merek suatu produk menciptakan citra dari produk itu sendiri di benak pikiran konsumen dan menjadikan motivasi dasar bagi konsumen dalam memilih suatu produk. 


\section{b. Pengaruh Harga terhadap Kepuasan Pelanggan}

Harga, dilihat dari sudut pandang konsumen, seringkali digunakan sebagai indikator nilai bilamana harga tersebut dihubungkan dengan manfaat yang dirasakan atas suatu barang atau jasa. Pada tingkat harga tertentu, jika manfaat yang dirasakan meningkat, maka nilainya akan meningkat pula. Apabila nilai yang dirasakan pelanggan semakin tinggi, maka akan menciptakan kepuasan pelanggan yang maksimal (Tjiptono, 2008; 152). Kertajaya (2006) indikator dari harga dapat dinyatakan dalam penilaian konsumen terhadap besarnya pengorbanan financial yang diberikan dalam kaitannya dengan spesifikasi yang berupa kualitas produk. Selain itu penilaian harga dapat dilihat dari kesesuaian antara suatu pengorbanan dari konsumen terhadap nilai yang diterimanya setelah melakukan pembelian, dan dari situlah konsumen akan mempersepsikan dari produk atau jasa tersebut. Persepsi yang postif merupakan hasil dari rasa puas akan suatu pembelian yang dilakukannya, sedangkan persepsi yang negatif merupakan suatu bentuk dari ketidakpuasan konsumen atas produk atau jasa yang dibelinya.

\section{c. Pengaruh Kualitas pelayanan terhadap Kepuasan Pelanggan}

Sebagaimana telah diuraikan di muka bahwa kualitas pelayanan yang sangat berpengaruh terhadap kepuasan pelanggan. Keberhasilan perusahaan dalam memberikana pelayanan yang berkualitas dapat ditentukan dengan pendekatan service quality, menurut Parasuraman et al (dalam Lupiyoadi, 2006:181). Dalam usaha melayani kebutuhan konsumen di bidang jasa, kualitas pelayanan yang diberikan pihak penjual memainkan peranan penting dalam memberi nilai tambah terhadap pengalaman service secara keseluruhan. Sama seperti halnya kualitas produk, seorang pelanggan akan mengevaluasi kualitas layanan berdasarkan persepsi mereka. Menurut Brady dan Cronin (dalam Remiasa dan Lukman, 2007) persepsi pelanggan terhadap kualitas layanan ini terdiri dari tiga kualitas yaitu kualitas interaksi, kualitas lingkungan fisik dan kualitas hasil. Ketiga kualitas ini membentuk pada keseluruhan persepsi pelanggan terhadap kualitas layanan.

\section{d. Pengaruh Citra Merek, Harga Dan Kualitas Pelayanan terhadap Kepuasan Pelanggan}

Citra merek merupakan logo perusahaan jasa pengiriman yang akan dijual kepada pelanggan, sedangkan harga merupakan panduan untuk para konsumen untuk menjadi pelanggan yang baik dalam jasa pengiriman sedangkan kualitas pelayanan yang baik akan dapat mendatang pelanggan yang lain untuk jasa pengiriman. Guna merebut dan mempertahankan pelanggan diperlukan strategi yang membutuhkan komitmen, baik dana maupun sumber daya manusia yang tujuannya agar jasa pengiriman yang ditawarkan sesuai dengan keinginan pelanggan sehingga dapat memberikan kepuasan pelanggan. Bagi perusahaan agar dapat meningkatkan dan mempertahankan pelanggan salah satunya dengan memberikan nilai dan kepuasan pelanggan serta menjadi ciri pembeda jasa pengiriman dengan jasa pengiriman pesaing. Hal ini dapat dilakukan dengan mengembangkan strategi diferensiasi produk agar dapat memberikan nilai jasa yang berbeda dengan pesaing, keadaan tersebut akan meningkatkan kepuasan pelanggan. Dalam menciptakan kepuasan pelanggan, perusahaan harus dapat meningkatkan citra merek dan kualitas pelayanan. Kepuasan pelanggan dapat diciptakan melalui citra merek dan harga dari para pelanggannya. Semakin baik penilaian dan citra pelanggan, akan semakin tinggi pula kepuasan pelanggan. Tingginya kepuasan pelanggan juga tidak lepas dari dukungan internal perusahaan, terutama dukungan dari sumber daya manusianya. Sehingga dapat diduga terdapat pengaruh citra merek, harga dan kualitas pelayanan secara bersama terhadap kepuasan pelanggan. 


\section{METODE PENELITIAN}

Variabel dependen adalah variable yang menjadi pusat perhatian utama peneliti. Hakekat sebuah masalah mudah terlihat dnegan mengenali berbagai variabel dependen yang digunakan dalam sebuah model. Variabilitas dari atau atas faktor inilah yang berusaha untuk dijelaskan oleh seorang peneliti (Ferdinand, 2006:26). Dalam penelitian ini yang menjadi variabel dependen adalah : kepuasan Pelanggan ( $\mathrm{Y}$ ). Variabel independen yang dilambangkan dengan $(\mathrm{X})$ adalah variabel yang mempengaruhi variabel dependen, baik yang pengaruhnya positif maupun yang pengaruhnya negatif (Ferdinand, 2006:26). Variabel independen dalam penelitian ini adalah Citra Merek (X1), Harga ( X2) dan Kualitas Pelayanan ( $\mathrm{X} 3)$.

\section{Populasi Dan Sampel Yang Digunakan}

Menurut Sugiyono (2007:72), "Populasi adalah wilayah generalisasi yang terdiri atas objek atau subjek yang mempunyai kualitas dan karakteristik tertentu yang ditetapkan oleh peneliti untuk dipelajari dan kemudian ditarik kesimpulannya". Menurut Sugiyono (2007:73), "Sampel adalah bagian dari jumlah dan karakteristik yang dimiliki oleh populasi tersebut ". Sampel merupakan bagian kecil dari populasi yang menjadi objek penelitian. Di dalam penelitian ini yang akan dijadikan sampel sebagai responden adalah pelanggan PT. Pos Indonesia (persero) Medan, peneliti menggunakan penentuan ukuran sampel dengan menggunakan Rumus Slovin. Untuk menetapkan sampel dari suatu populasi dapat ditentukan dengan menggunakan rumus Slovin. Maka dapat diperoleh jumlah sampel penelitian sebanyak 100 orang responden

\section{HASIL DAN PEMBAHASAN}

Analisis Regresi Berganda

Adalah regresi dimana variabel terikatnya (Y) dihubungkan atau dijelaskan lebih dari 1 variabel mungkin 2,3, dan seterusnya, variabel bebas $(\mathrm{X} 1, \mathrm{X} 2, \mathrm{X} 3 \ldots \mathrm{Xn})$ namun masih menunjukkan diagram hubungan yang linear. Penambahan variabel bebas ini diharapkan dapat lebih menjelaskan karakteristik hubungan yang ada walaupun masih saja ada variabel yang terabaikan. Menurut sugiyono (2007, p:210-211) analisis regresi berganda digunakan untuk meramalkan bagaimana keadaan (naik turunya) variabel dependen (kriterium), bila dua atau lebih variabel independen sebagai faktor prediktor dimanupulasi (dinaik turunkan nilainya). jadi analisis regresi ganda akan dilakukan bila jumlah variabel independenya minimal dua. Analisis regresi berganda digunakan untuk meramalkan bagaimana fluktuasi variabel dependen melalui dua atau lebih variabel independen. Dalam penelitian ini ada tiga varabel independen yang akan digunakan yaitu citra merek, harga dan kualitas pelayanan. Sedangkan yang akan menjadi variabel dependennya adalah kepuasan pelanggan. Dari hasil perhitungan di atas dapat diperoleh rumusan persamaan regresi linier berganda untuk variabel independen (citra merek, harga dan kualitas pelayanan) terhadap variabel dependen (kepuasan pelanggan) sebagai berikut:

$$
\hat{\mathrm{Y}}=2.948+1.115 \mathrm{X} 1+0.855 \mathrm{X} 2+0.437 \mathrm{X} 3
$$

Hasil perhitungan analisis mengidentikasikan bahwa nilai a (konstanta) sebesar 2.948 berarti jika tidak ada perubahan variabel independen (citra merek, harga dan kualitas pelayanan), maka kepuasan pelanggan 2.948. Nilai b1 (koefisien untuk citra merek) sebesar 1.115 menunjukkan adanya pengaruh positif citra merek terhadap kepuasan pelanggan, berarti bahwa tiap kenaikan sebesar 1 satuan pada citra 
merek akan meningkatkan kepuasan pelanggan sebesar 1.115 dengan asumsi harga dan kualitas pelayanan dianggap tetap. Nilai b2 (koefisien untuk harga) sebesar 0.855 menunjukkan adanya pengaruh positif harga terhadap kepuasan pelanggan, berarti bahwa tiap kenaikan sebesar 1 satuan pada harga akan meningkatkan kepuasan pelanggan sebesar 0.855 dengan asumsi kualitas pelayanan dan citra merek dianggap tetap. Nilai b3 (koefisien untuk kualitas pelayanan) sebesar 0.437 menunjukkan adanya pengaruh positif kualitas pelayanan terhadap kepuasan pelanggan, berarti bahwa tiap kenaikan sebesar 1 satuan pada kualitas pelayanan akan meningkatkan kepuasan pelanggan sebesar 0.437 dengan asumsi citra merek dan mutu produk dianggap tetap. Berdasarkan persamaan regresi di atas dapat ditarik kesimpulan bahwa variabel yang paling dominan mempengaruhi kepuasan pelanggan adalah citra merek karena menunjukkan nilai pengaruhnya sebesar 1.115 dan diikuiti oleh variabel harga dan kualitas pelayanan dengan besar pengaruhnya masing-masing sebesar 0.855 dan 0.437 .

\section{KESIMPULAN}

1. Citra Merek berpengaruh positif dan signifikan terhadap Kepuasan Pelanggan pada PT. Pos Indonesia (Persero) Medan, dengan besaran koefisien regresi $(\mathrm{b} 1)=1.419$ dan $\mathrm{t}$ hitung $=26.220>\mathrm{t}$ table 1.986 .

2. Harga berpengaruh positif dan signifikan terhadap Kepuasan Pelanggan pada PT. Pos Indonesia (Persero) Medan, dengan besaran koefisien regresi $(b 2)=1.194$ dan $\mathrm{t}$ hitung $=19.819>\mathrm{t}$ table $=1.986$.

3. Kualitas Pelayanan berpengaruh positif dan signifikan terhadap Kepuasan Pelanggan pada PT.Pos Indonesia (Persero) Medan, dengan besaran koefisien regresi $(\mathrm{b} 3)=0.923$ dan tingkat signifikan $\mathrm{t}$ hitung $17.162>\mathrm{t}$ table 1.986.

4. Citra Merek, Harga dan kualitas pelayanan secara bersama-sama berpengaruh positif dan signifikan terhadap Kepuasan Pelanggan dengan besaran koefisien antara masing-masing yaitu : b1 = 1.115, b2 = 0,855 dan $\mathrm{b} 3=0.437$, dan tingkat signifikan $\mathrm{t}$ hitung 287,915 > F tabel 2,708. Hal ini menunjukkan semua variabel independent terbukti berpengaruh positif dan signifikan terhadap variabel dependent dan variabel citra merek yang lebih dominan mempengaruhi Kepuasan Pelanggan pada PT.Pos Indonesia (Persero) Medan.

\section{DAFTAR PUSTAKA}

Abdul Ghanir, 2012, Pengaruh Kualitas pelayanan terhadap Kepuasan Pelanggan Pada Rumah Sakit Umum Daerah Kota BauBau

Arifianto, E. 2005. Persepsi Tentang Kriminalitas dan Kecemasan Pada Perempuan. Skripsi (tidak Diterbitkan). Yogyakarta: Fakultas Psikologi Universitas Wangsa Manggala

Bahar, Taslim, Kusbiantoro, Tamim dan Frazilla. 2009. Pengaruh Kualitas Pelayanan Terhadap Kepuasan Dan Loyalitas Penggunaan Moda Angkutan Umum Informal. Simposium XII FSTPT, Universitas Kristen Petra Surabaya, 14 November 2009. http://repository.petra.ac.id/14461/1/115.pdf Buchari Alma, (2006). Pemasaran dan Pemasaran Jasa, Alfabeta, Bandung Dharmesta \& Irawan. (2005). Manajemen Pemasaran Modern. Edisi Kedua. Yogyakarta: Liberty. 
Dharmmesta, Basu Swastha., Handoko, T. Hani. 2012. Manajemen Pemasaran Analisis Perilaku Konsumen. Edisi Pertama. BPFE, Yogyakarta.

Effendi M. Guntur, 2009. Transformasi Manajemen Pemasaran + Membangun Citra Negara. Jakarta: Sagung Seto

Fandy Tjiptono, 2006, Manajemen Pelayanan Jasa, Penerbit Andi, Yogyakarta

Fandy Tjiptono, 2007, Strategi Pemasaran. Edisi ke dua, penerbit Andi, Yogyakarta.

Fandy Tjiptono, 2008, Strategi Bisnis Pemasaran. Andi. Yogyakarta.

Fandy Tjiptono dan Gregorius Chandra. 2011. Service, Quality \& Satisfaction Edisi 3. Yogyakarta: ANDI Fandy Tjiptono dan Gregorius Chandra, (2012). Pemasaran Strategik. Edisi Kedua. Andi, Yogyakarta.

Ghozali, Imam, 2007, Aplikasi Analisis Multivariat dengan Program SPSS. Badan Penerbit Universitas Diponegoro, Semarang.

Gujarati, Damodar. 2006. Dasar-Dasar Ekonometrika.Jakarta: Erlangga.

Handi Irawan. (2009). 10 Prinsip Kepuasan Pelanggan. Jakarta: PT. Elex Media Komputindo

Handri Agus Sukendro (2012). Pengaruh Citra Merek dan Kualitas Pelayanan Terhadap Kepuasan Jama'ah pada Kelompok Bimbingan Haji (KBIH) Indosat Medan

Hermawan Kartajaya. 2006. Hermawan Kartajaya on Segmentation Seri 9 Elemen Marketing. Bandung: PT. Mizan Pustaka

Hermann et al. 2007. "The Influence of Price Fairness on Customer Satisfaction: An Empirical Test in The Context of Automobile Purchases”. Journal of Product \& Brand Management. Vol.16, No.1, pp 49-58.

Jacub, DR Rudy dan Fajar Laksono. 2012. Pengaruh Pelayanan dan Harga parepart Terhadap Kepuasan Pelanggan Studi Kausal Bengkel Cahaya Motor Yamaha-Jakarta. Jurnal Ilmiah Penelitian Manajemen Vol. 10 No.1. Surabaya: Program Pasca Sarjana Universitas Jayabaya.

Jugdip \& Lele, (2000). Model kepuasan Pelanggan Sebagai Moderating Variabel Guna Meningkatkan Loyalitas Pelanggan pada Maskapai Penerbangan, Jurnal Mikro Ekonomi dan Manajemen Bisnis

Kahle, L. R. \& Kim, CH. (eds). (2006). Creating Images and the Psychology of Marketing Communication. New Jersey: LEA

Kotler, Philip dan A.B Susanto. 2000.Manajemen Pemasaran di Indonesia, Salemba Empat, Jakarta

Kotler, Philip. (2005 ). Manajemen Pemasaran, alih bahasa, Benyamin Molan ;penyunting Bambang Sarwiji. Jilid satu Edisi Sebelas, Penerbit PT. Indeks, Jakarta.

Kotler, Philip. 2006. Manajemen Pemasaran Edisi 11. Jakarta: PT. Indeks

Kotler, Philip and Gary Amstrong, 2007. Dasar-Dasar Pemasaran Edisi Kesembilan Jilid I, PT Indeks, Jakarta

Kotler, Philip dan Kevin lane Keller, 2007, Manajemen Pemasaran, Edisi 12, Jilid-2, PT. Indeks, Jakarta. 
Kotler, Philip dan Armstrong, Gary, 2008, Prinsip - Prinsip Pemasaran. (Alih bahasa Bob Sabran). Jilid 1. Edisi keduabelas. Erlangga, Jakarta. (Buku asli edisi 12).

Kotler, Philip; Armstrong, Garry, 2008. Prinsip-prinsip Pemasaran, Jilid 1, Erlangga, Jakarta.

Kotler, Philip. 2009. Manajemen Pemasaran. Jakarta : Erlangga. Laksana, Fajar.

Lupiyoadi, Rambat. 2006. Manajemen Pemasaran Jasa. Ed. 2. Jakarta : Salemba Empat.

Philip Kotler and Kevin Lane Keller, Alih Bahasa Benyamin Molan ,2007, Manajemen Pemasaran, Edisi Keduabelas, Jilid 1, PT. Indeks.

Purba, Amir, Dewi Kurniawati, Fatmawaty Lubis, Dayana, dan Haris Wijaya. (2006)."Pengantar Ilmu Komunikasi”. Pustaka Bangsa Press, Medan

Philip Kotler \& Kevin Lane Keller, 2009, Manajemen pemasaran, Edisi 13 Jilid 2. Jakarta.

Rangkuti, F. 2008. Analisa SWOT Teknik Membedah Kasus Bisnis. Jakarta : PT.Gramedia Pustaka Utama

Ratminto \& Atik Septi W, 2005. Manajemen Pelayanan. Yogyakarta : Pustaka Pelajar

Remiasa dan Lukman. 2007. “Analisis Persepsi Pelanggan Terhadap Kualitas Layanan Coffee Shop Asing dan Coffee Shop Lokal". Jurnal Manajemen Perhotelan. Vol.3 No.2. Universitas Petra, Surabaya

Saladin, Djaslim, 2006, Manajemen Pemasaran, Edisi Keempat, Bandung : Linda Karya.

Setiadi, Nugroho J. 2003, Perilaku Konsumen. Kencana. Jakarta

Sugiyono. 2007. Statistika Untuk Penelitian. Bandung: ALFABETA.

Sugiyono, (2008). Metode Penelitian Kunatitatif Kualitatif dan R\&D. Bandung Alfabeta

Sumarwan, Ujang. Perilaku Konsumen. 2004, Bogor, Ghalia Indonesia

Supranto, J., 2006, Pengukuran Tingkat Kepuasan Pelanggan : Untuk Menaikkan Pangsa Pasar, Jakarta, Rineka Cipta

Supranto, J dan Limakrisna. 2007. Perilaku Konsumen dan Strategi Pemasaran Untuk Memenangkan Persaingan Bisnis. Mitra Wacana Media, Jakarta.

Suwandi (2015). Pengaruh Kualitas Pelayanan, Harga Dan Citra Merek Terhadap Kepuasan Dan Loyalitas Pelanggan Pos Ekspres Di Kantor Pos Bondowoso Dan Situbondo

Umar, Husein, 2010, Metode penelitian untuk skripsi dan tesis bisnis, penerbit jakarta rajawali

Wicaksono, Ananto Sarono, 2007. Analisis Pengaruh Rasio Keuangan Terhadap harga Saham. Skripsi S1

Zinkhan, Price, Arnould. 2005. Consumers, second Edition. Mcgraw-Hill/Irwin. 